\title{
Liver pathology in fishes from the Lower Elbe as a consequence of pollution
}

\author{
N. Peters, A. Köhler \& H. Kranz \\ Zoologisches Institut und Zoologisches Museum, Universität Hamburg, Martin-Luther-King-Platz 3, D-2000 Hamburg 13, \\ Federal Republic of Germany
}

\begin{abstract}
In flounder Platichthys flesus, ruffe Gymnocephalus cernua, and smelt Osmerus eperlanus, caught mainly during 1980 through 1983 in the Lower Elbe, a large number of serious pathological liver conditions were diagnosed. The predominant symptom was a shrinkage of liver cells, which spreads with advancing age and is increasingly accompanied by other degenerative changes, such as dissolution of the well-organized liver structure, blood clots, and tissue necroses. Neoplastic liver nodules were found in $32 \%$ of sexually mature ruffe. Elbe flounders, which mature sexually shortly after migrating to their spawning grounds in the southern North Sea, still showed no signs of such nodules. In contrast, recent investigations of sexually mature flounders off the Dutch coast revealed occurrence rates as high as $10 \%$. Fishes from the River Eider, in which pollution is minimal, were effectively free from such liver damage. The livers of some $1 \mathrm{yr}$ old flounders from the Lower Elbe, kept for $40 \mathrm{~d}$ in uncontaminated water and fed on a diet free of harmful substances, showed signs of regeneration along with a decrease in chlorinated hydrocarbon content. Livers of other fishes kept under the same conditions maintained their high chlorinated hydrocarbon concentrations and continued to display the pathological liver symptoms. That the liver damage observed in Elbe fishes is due to high pollution levels receives support from 2 facts: (1) Other authors found similar pathological liver conditions in coastal regions where the pollution level was high; (2) liver conditions of this kind could be induced experimentally in fishes by PCBs in concentrations of the same order of magnitude as those recorded in the Lower Elbe.
\end{abstract}

\section{INTRODUCTION}

\section{Fish diseases in coastal regions}

There have been an increasing number of reports in the literature that generally known fish diseases, such as skin ulcerations, fin rot, lymphocystis, and skeletal anomalies, occur with particularly high frequency in marine coastal regions. Reviews of this problem have been provided by Sindermann $(1979,1983)$, Peters (1981), Dethlefsen (1985), and Dethlefsen \& Tiews (1985). The fact that, in many cases, such coastal regions are considered heavily polluted with wastewater as well as the observed decrease in the frequency of these diseases toward the open sea suggest that there is a relationship between the degree of pollution and disease rates. This problem has been discussed with the German Bight as a case in point.

Coastal waters are sometimes directly contaminated from sewage outlets or by the dumping of wastes. However, when they receive the outflow of large riv- ers, a much larger volume of pollutants generally enter with the river water than originate from local sources. In any case, this is true for the German Bight, into which the Rivers Elbe and Weser flow (Sondergutachten Nordsee 1980). The load of harmful substances carried into the North Sea by the Elbe is second to that from the Rhine. Today, the Elbe is the river most contaminated with heavy metals in the German Federal Republic (Müller 1985). The concentration of many contaminants increases significantly, by as much as 2 or 3 orders of magnitude, from the open waters of the German Bight into the inner Elbe Estuary.

If there is actually a relation between water pollution and fish diseases, then it should be expected that this would become especially evident in the lower stretches of rivers, in particular, the Lower Elbe. However, the conditions influencing such a relationship are made extremely complicated by 2 circumstances: (1) fish diseases show an extraordinary dependence on the environment and especially on such factors as temperature and salinity, and (2) the estuary displays a pro- 
nounced longitudinal zonation not only in these parameters but also in a variety of others, even including the qualitative and quantitative food supply for the fishes. For these reasons, if an attempt were made to correlate the variation in disease rates with the pollution along a longitudinal section of the estuary, the results would not be at all convincing.

\section{Criteria for establishing a cause and effect relation between fish diseases and pollution}

A cause and effect relation would be indicated if a correlation were found between the disease rate and the distribution of wastewater within a narrowly delimited area. A second criterion for a causal relation is the detection of parallel tendencies for changes in the disease rate and pollution of the water over a long period of time. Both criteria are applicable mainly in cases of diseases that are widespread and not caused exclusively by man-made water pollution, although they may well be promoted by it.

A third criterion offers stronger proof. It is, met if diseases regularly occur in heavily polluted water but are very seldom, if ever, encountered in waters with little or no pollutants.

A fourth criterion serves to confirm the suspicion raised when one of the above 3 criteria are encountered. It is met if during long-term experiments employing controlled concentrations of contaminants in the water, the same disease symptoms and rates of infection as encountered among wild fishes can be produced. Even more convincing proof would be provided if the pathological symptoms can be induced by a single, or at least a small number of the suspected pollutants.

A fifth criterion is essentially a reversal of the first 3 . This is satisfied when a reduction in the water pollution, or in the concentrations of the major contaminants, results in a decline in the disease rate, if the condition is reversible. In experiments, maintaining the fishes in unpolluted water and feeding them uncontaminated food should result in relief from the disease.

A sixth criterion is a special variation of the other 5 . It is listed supplementally because of the convincing proof it offers. It is met by establishing that mainly those individuals contaminated by the greatest amounts of the pollutants are afflicted with the disease.

Certainly, each individual criterion alone can not offer positive proof that pollution is the main cause of or an essential factor in the development of the disease. The probability of this, however, increases greatly whenever 2 or more of these criteria are simultaneously fulfilled.
The following description of liver changes in flounder Platichthys flesus, ruffe Gymnocephalus cernua, and smelt Osmerus eperlanus from the Lower Elbe is provided with the goal of proving the causal relation between liver damage and pollution. Findings from previous investigations on degeneration, neoplastic nodules, and melanomacrophage centers of the liver (Köhler 1980, Köhler \& Hölzel 1980, Kranz \& Peters 1984, 1985, Köhler 1986) are summarized and supplemented with more recent discoveries. Most of the more than 1000 fishes examined were obtained from 1980 through 1983. For controls, over 200 specimens of the 3 species from the nearby Eider River estuary, which is much less polluted, were examined. For details on the collection and treatment of these specimens refer to the papers mentioned above.

\section{RESULTS}

\section{Liver degeneration}

The liver is the central metabolic organ of fishes and has numerous anabolic and catabolic functions. In contrast to the heterogeneous physiology of the organ, its structure is very homogeneous. The fish liver consists essentially of parenchyma tissue usually formed from double layers of liver cells separated from each other by capillary-like blood spaces called liver sinusoids. The liver is an organ that stores carbohydrates as glycogen and, especially before spawning, fats. The hepatocytes, which normally appear compact, may give the impression of being more or less vacuolized under the light microscope, according to the degree of fat storage.

A storage of a rich fat supply in the liver is scarcely ever encountered among juveniles or mature fishes after spawning. Therefore, the livers of the flounder, ruffe, and smelt captured in summer and autumn in the tidal regions of the relatively unpolluted Eider appear quite homogeneous (Fig. 1).

A very different impression is given by the liver of fishes in the same age groups from the Lower Elbe. The hepatic tissue in these appears spotted. Between the normally formed polygonal hepatocytes, slightly enlarged, rounded cells of lighter color are scattered together with considerably shrunken, concave cells of especially dark coloration (Fig. 2). These shrunken or condensed hepatocytes may be isolated, form reticulated groupings, or spread over large areas. The condensed cells contain very few fat droplets appearing dark after osmium fixation. In contrast, the shrunken cells often contain numerous clear vacuoles. Electron micrographs reveal these to be enormously swollen mitochondria, the ultrastructure of which has disinte- 


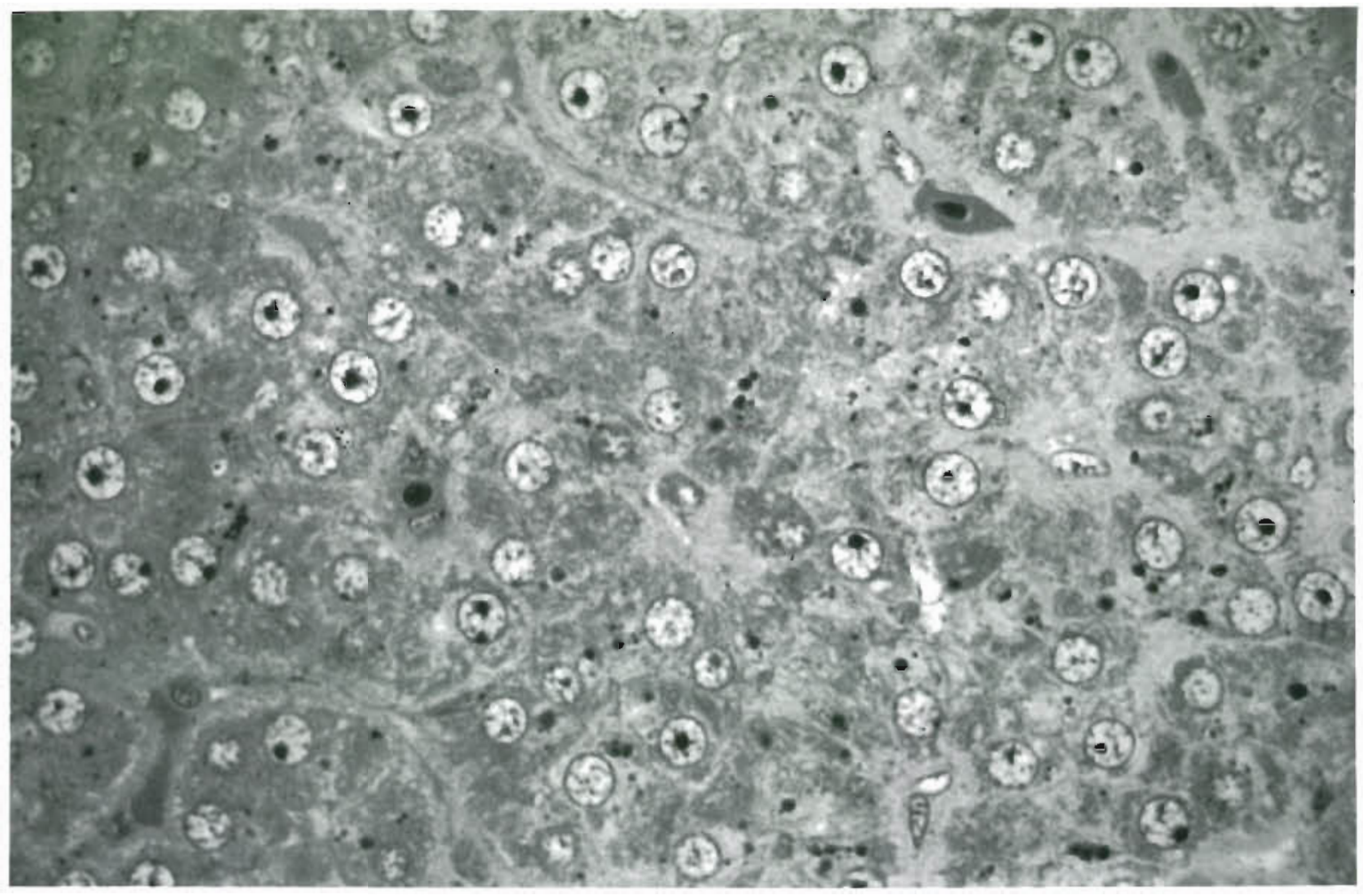

Fig. 1. Gymnocephalus cernua. Liver section of mature ruffe caught in the River Eider during summer; note fairly homogeneous structure. LM; Epon $1 \mu \mathrm{m}$; toluidine blue; $\times 1600$

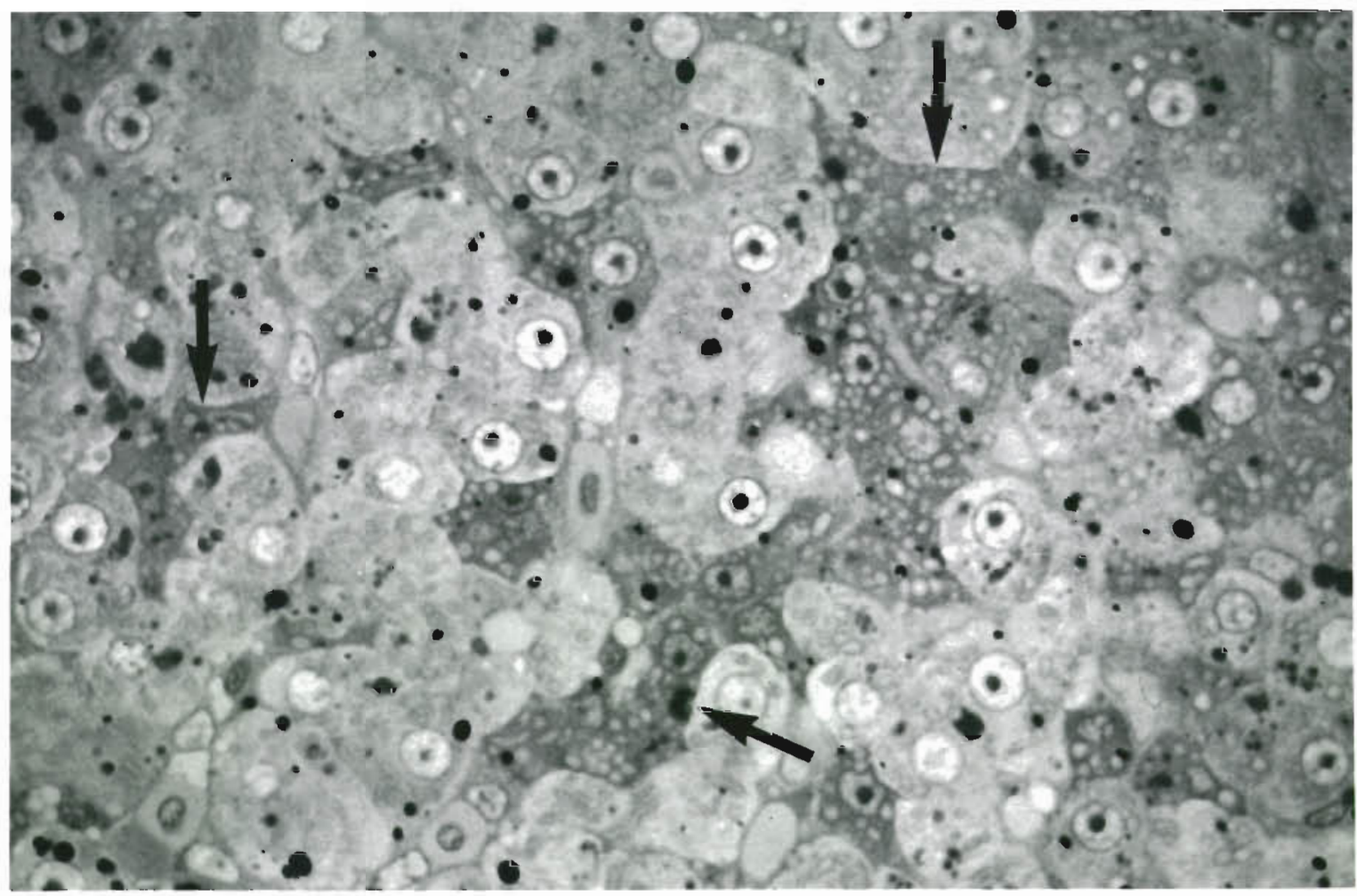

Fig. 2. Gymnocephalus cernua. Liver section of mature ruffe caught in the Lower Elbe during summer; note very unhomogeneous (spotted) structure with condensed (shrunken) hepatocytes (arrows). LM; Epon $1 \mu \mathrm{m}$; toluidine blue; $\times 1600$ 


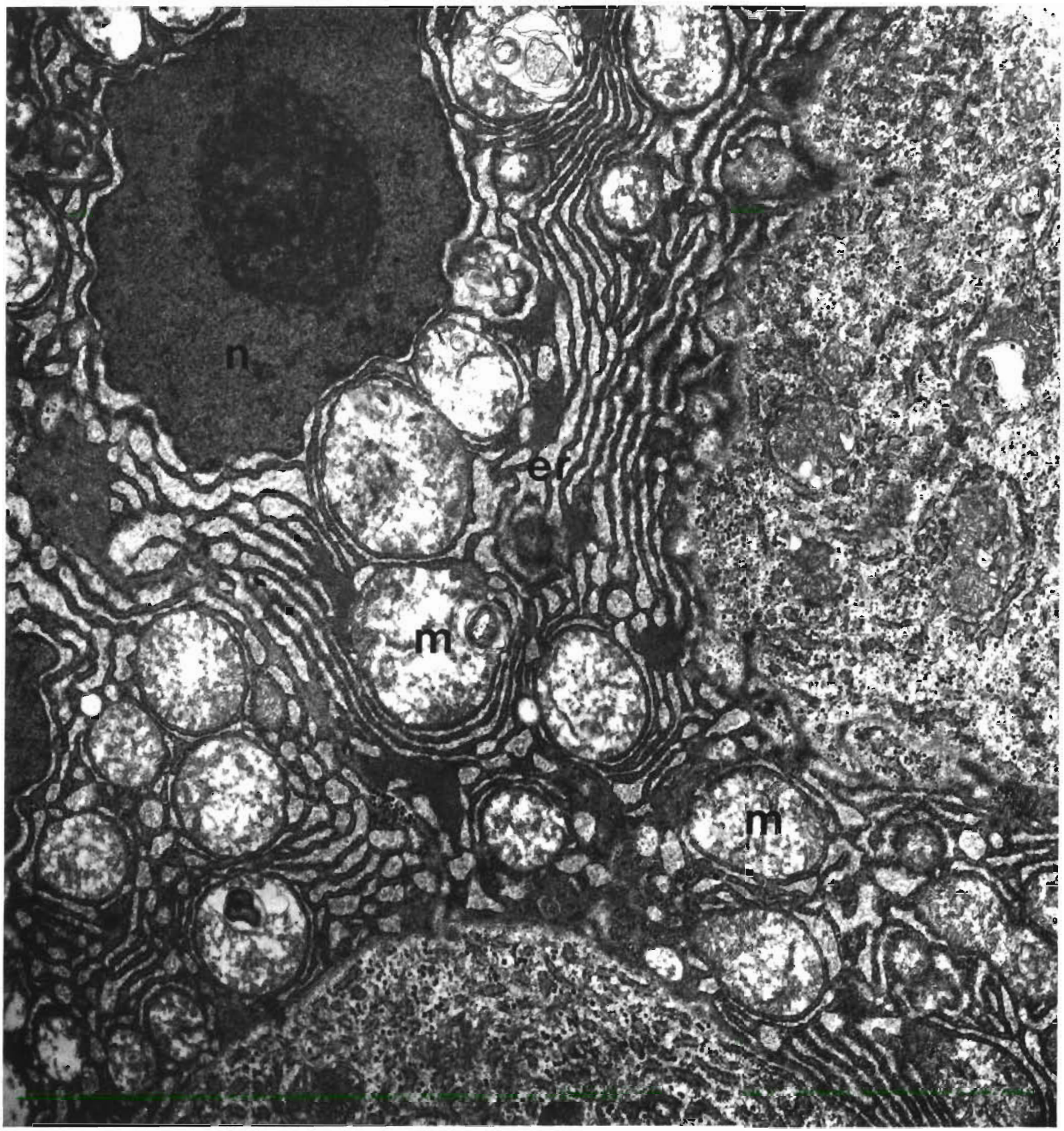

Fig. 3. Gymnocephalus cernua. Condensed (shrunken) hepatocytes of ruffe from the Lower Elbe. $\mathrm{n}$ : nucleus reduced in size, with crumpled surface; m: swollen mitochondria, er: dilated endoplasmic reticulum. EM; Epon $0.05 \mu$ m; uranyl acetate/lead citrate; $\times 24000$

grated so much that it can scarcely be recognized (Fig. 3) ${ }^{*}$. Other characteristics of the condensed hepatocytes

- In the flounder, the mitochondria of the condensed cells undergo destruction more by diffuse than by clear swelings include a significantly smaller nucleus with a crumpled membrane and sometimes a swollen rough endoplasmic reticulum.

The condition of the condensed cells is variable. Hepatocytes may be found in all stages from normal to 
the conditions described above. Cells that are shrunken to the extent of appearing crushed flat and lacking almost all inner organization are also regularly observed. This totally collapsed condition must be considered necrotic.

Liver cell shrinkage is not the only observed characteristic of degeneration. With increasing age of the fish, there are also other diverse changes, including hepatocytomegaly, which is an excessive hypertrophy of individual liver cells; local blood congestions in the liver sinusoids; an increasing dissolution of the otherwise very pronounced organization of the liver cell strings (trabeculae); and a tissue necrosis that spreads over increasingly large areas and involves fibrosis, by which the fibrous connective tissue from the liver capsule and the walls of large blood vessels spread to fill the gaps left by the degenerating cells (Fig. 4a). The excessive deposition of fat is especially evident. The large central fat vacuole forces the nucleus of the hepatocyte to the edge of the cell and may even flatten

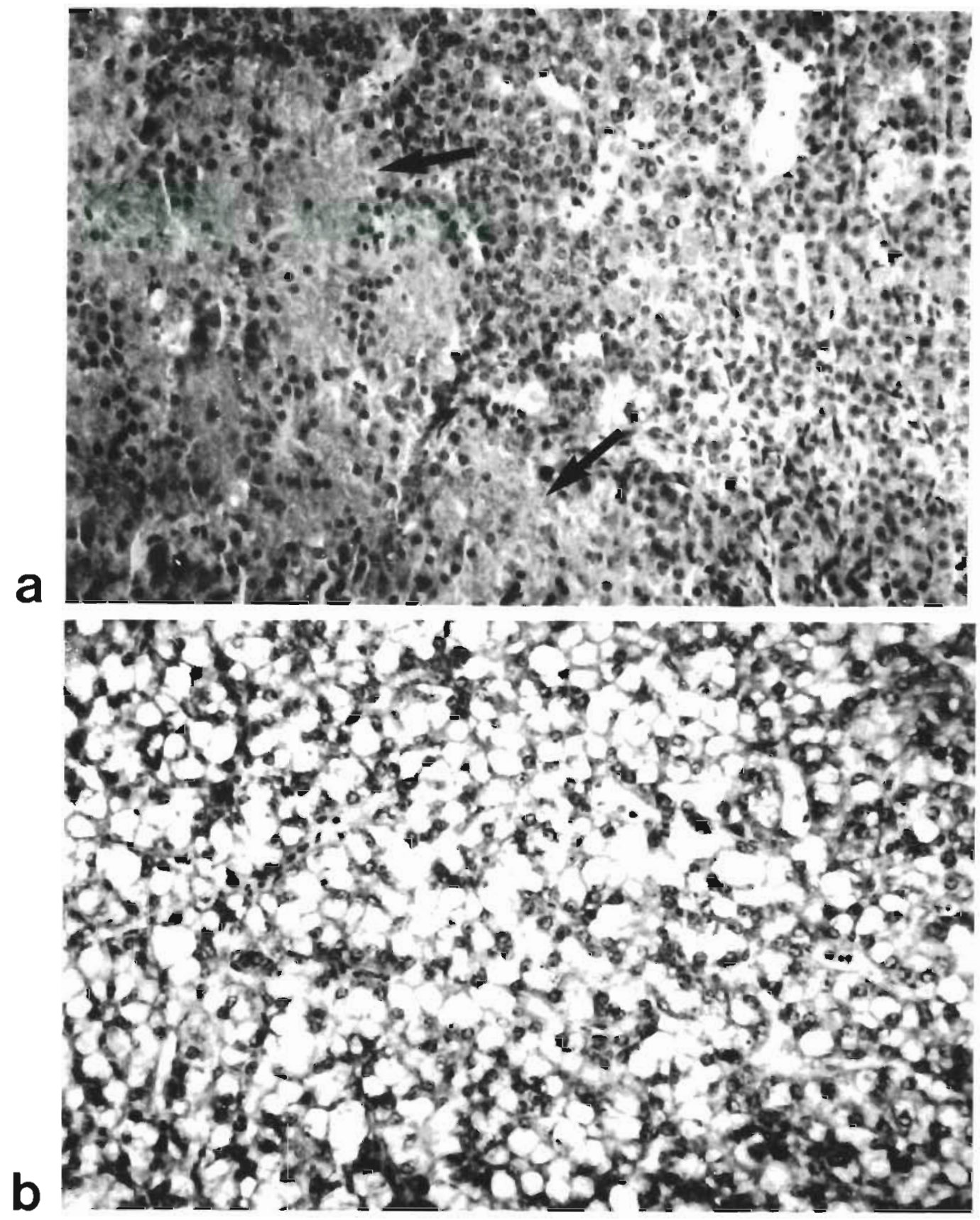

Fig. 4. Gymnocephalus cernua. Liver tissue of ruffe from the Lower Elbe (a) with local deterioration of liver parenchyma replaced by fibrous connective tissue (arrows), (b) with excessive fat storage. LM; paraffin $5 \mathrm{um} ; \mathrm{H} / \mathrm{E}_{;} \times 400$ 
Table 1. Platchthys flesus. Frequency of pathological liver symptoms in flounder from the Rivers Elbe and Eider (F.R. Germany) in \% (rounded). Station 1: Elbe near Fährmannsand, $80 \mathrm{~km}$ from river mouth; Station 2: Elbe near Brunsbüttel, $20 \mathrm{~km}$ from river mouth; Station 3: Eider, lower tidal area. Flounder specimens grouped into age classes: $0 \mathrm{a}=$ up to $3 \mathrm{~cm}$ TL (Jun); $0 \mathrm{~b}=\mathrm{up}$ to $9 \mathrm{~cm}$ TL $(O c t) ; I=$ up to $14 \mathrm{~cm} \mathrm{TL;} \mathrm{II} \mathrm{=} \mathrm{up} \mathrm{to} 19 \mathrm{~cm} \mathrm{TL}$ III = up to $25 \mathrm{~cm}$ TL. Total number of specimens $\mathrm{n}=150$. Modified after Köhler 1986

\begin{tabular}{|c|c|c|c|c|c|c|c|c|c|c|c|c|c|c|c|}
\hline \multirow[t]{2}{*}{ Type of degeneration } & \multicolumn{5}{|c|}{ Station 1} & \multicolumn{5}{|c|}{ Station 2} & \multicolumn{5}{|c|}{ Station 3} \\
\hline & $0 \mathrm{a}$ & $\mathrm{Ob}$ & I & II & III & $0 \mathrm{a}$ & $\mathrm{ob}$ & $\mathrm{I}$ & II & III & $0 \mathrm{a}$ & $0 b$ & I & II & III \\
\hline $\begin{array}{l}\text { 0: Nearly normal liver } \\
\text { structure }\end{array}$ & 100 & - & 7 & - & - & 100 & 40 & 22 & 14 & 25 & 100 & 100 & 84 & 88 & 75 \\
\hline $\begin{array}{l}\text { 1: Single shrunken } \\
\text { hepatocytes }\end{array}$ & - & - & 7 & - & - & - & 22 & 11 & 14 & 11 & - & - & 16 & 12 & 25 \\
\hline $\begin{array}{l}\text { 2: Liver cell strings sporadi- } \\
\text { cally disintegrated; clusters } \\
\text { of shrunken hepatocytes; } \\
\text { blood congestion and } \\
\text { hepatocytomegaly in places }\end{array}$ & - & 46 & 43 & 29 & 39 & - & 24 & 67 & 57 & 32 & - & - & - & - & - \\
\hline $\begin{array}{l}\text { 3: Atypical structure of all the } \\
\text { liver parenchyma (most } \\
\text { liver cell strings disinte- } \\
\text { grated); wide areas of } \\
\text { shrunken hepatocytes; } \\
\text { blood congestion; conspicu- } \\
\text { ous fat storage; frequent } \\
\text { necrotic and fibrous areas }\end{array}$ & - & 54 & 43 & 71 & 61 & - & 14 & - & 15 & 32 & - & - & - & - & - \\
\hline
\end{tabular}

it (Fig. 4b). These fatty deposits are obvious macroscopically as a mottling or even total whitening of the liver.

All of these conditions are distributed very irregularly throughout a single liver. The variability among individuals is even greater. The degree of degeneration of a single liver is judged according to the number of degenerative characteristics observed. A more accurate quantitative evaluation would not be possible without an enormous effort. Among all of the 1 to $3 \mathrm{yr}$ old Elbe flounder examined, more than $35 \%$ displayed the degeneration symptoms described (Table 1).

It could well be expected that the very numerous histological changes in the liver include a considerable number of ultrastructural aberrations. The detailed paper by Köhler (1986) on this problem is recommended.

\section{Neoplastic changes in the liver}

There are indications in the literature that fishes with considerable liver degeneration show a tendency toward the formation of liver tumors (Pierce et al. 1978, Smith et al. 1979). Neoplastic growths in the liver appear externally as nodules about the size of a pinhead or as lumps from several millimeters to about a centimeter in diameter, which appear notably lighter than the surrounding tissue when they form on or near the surface of the organ (Fig. 5). Even during the early stages of growth, a slight outward swelling of the tissue is usually evident. In histological preparations, the nodules can be recognized by their characteristic affinity for the stains; they are usually basophilic (Fig. 6). As a result of the widening of the liver sinusoids, the organization of the liver cell strings becomes even more evident than in normal liver tissue. The hepatocytes of the neoplastic nodules are often slightly enlarged, and the nucleus/plasma ratio is frequently increased. The cells hardly ever contain obvious inclusions. Melanomacrophage centers - uniformly distributed groups of pigmented phagocytotic cells near the sinusoids - are absent from the nodules. The border between nodule and normal liver tissue is well marked. When the neoplastic region is relatively large, the neighboring normal tissue is compressed and begins to atrophy, apparently due to the rapid growth of the neoplasm (Fig. 7). The formation of such neoplastic nodules generally marks the beginning of liver cancer in the fish, such as that known in cultured trout (Peters 1984).

We have not been able to find any such liver nodules in Elbe flounder of Year Classes 0 to III and of a maximum total length under $30 \mathrm{~cm}$. In contrast, 44 of the 551 ruffe $(8 \%)$ from the Lower Elbe were clearly afflicted. Among these, the nodules were not equally distributed among all size groups but rather appeared first in individuals with total lengths of at least $17 \mathrm{~cm}$ 


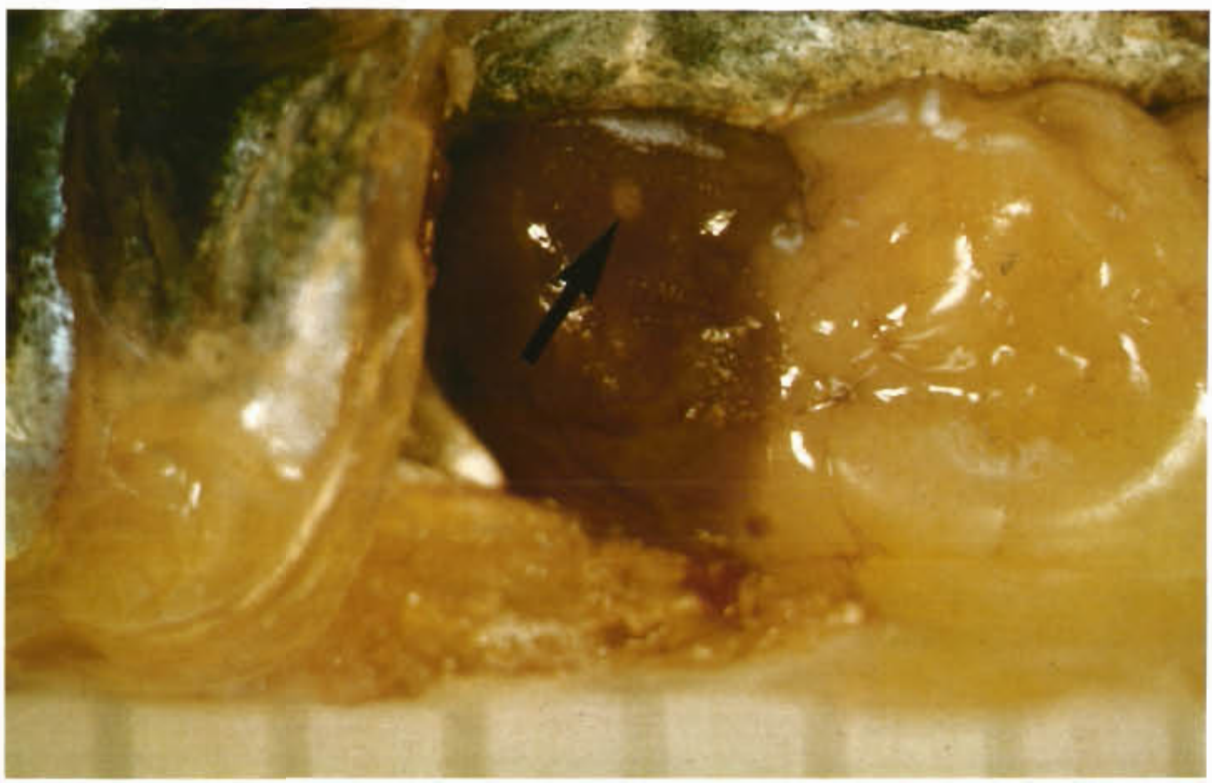

Fig. 5. Gymnocephalus cernua. Neoplastic nodule at the liver surface of ruffe from the Lower Elbe (arrow). Unstained total preparation; about double natural size

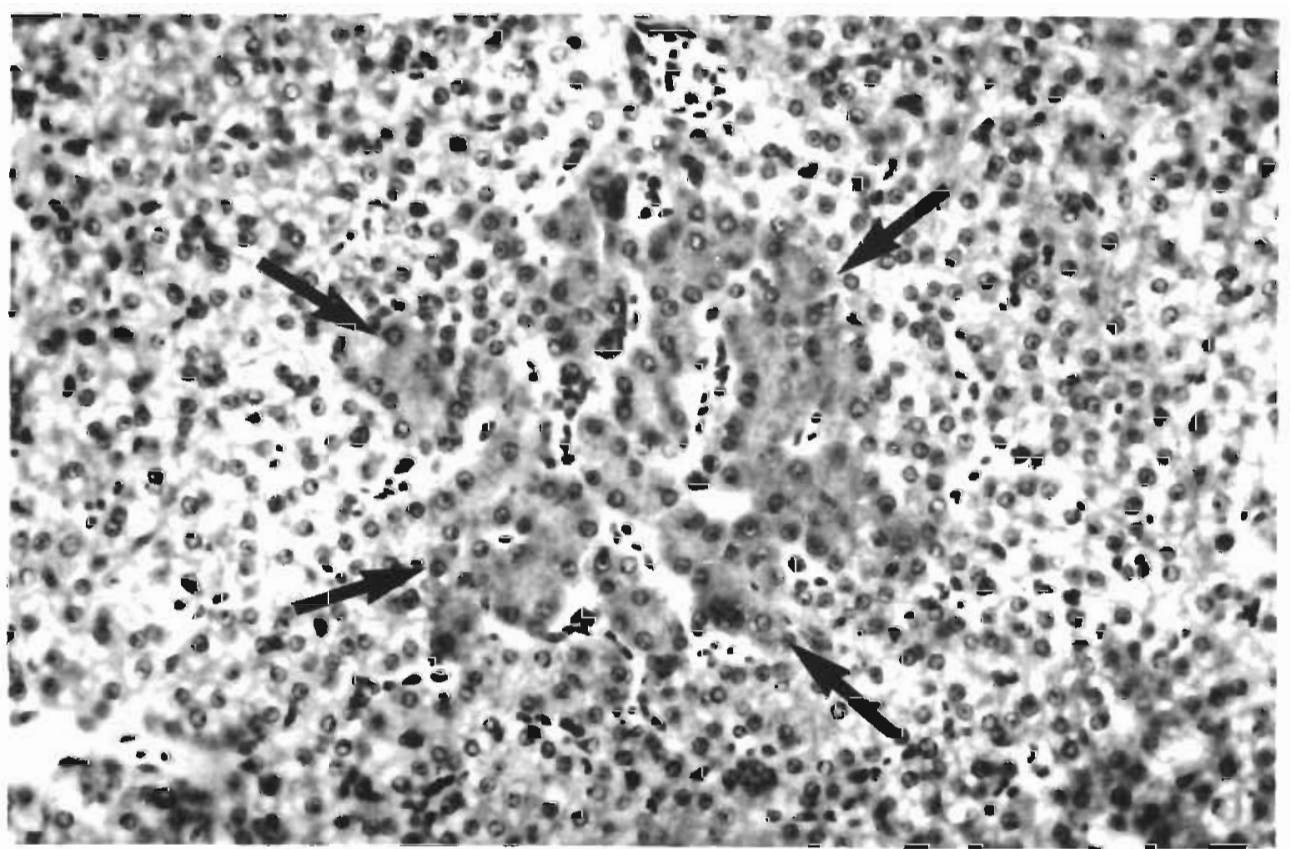

Fig. 6. Gymnocephalus cernua. Neoplastic nodule (early stage) staining basophilic in liver section of ruffe from the Lower Elbe; arrows mark the border against normal liver tissue. LM; paraffin $5 \mu \mathrm{m} ; \mathrm{H} / \mathrm{E}_{;} \times 400$

and became more numerous as the size of the fishes increased (Fig. 8).

According to Knowles (1974), a $17 \mathrm{~cm}$ ruffe from the Lower Elbe is at least $3 \mathrm{yr}$ old. Sexual maturity is

- Among ruffe $17 \mathrm{~cm}$ or larger, the rate of occursence was $32 \%$. Because only those nodules were counted that were visible on the surface of the liver, the actual rate of occurrence could have been significantly higher already reached at the age of 2 and a total length of about $12 \mathrm{~cm}$. Elbe flounders reach sexual maturity at an age of 3 to $4 \mathrm{yr}$ and a length of 25 to $30 \mathrm{~cm}$, shortly after they have migrated from the Lower Elbe into the North Sea. After spawning in the German Bight or the southern North Sea, the flounders distribute themselves mainly in the Wadden Sea but no longer make excursions into the rivers. The latest investigations 


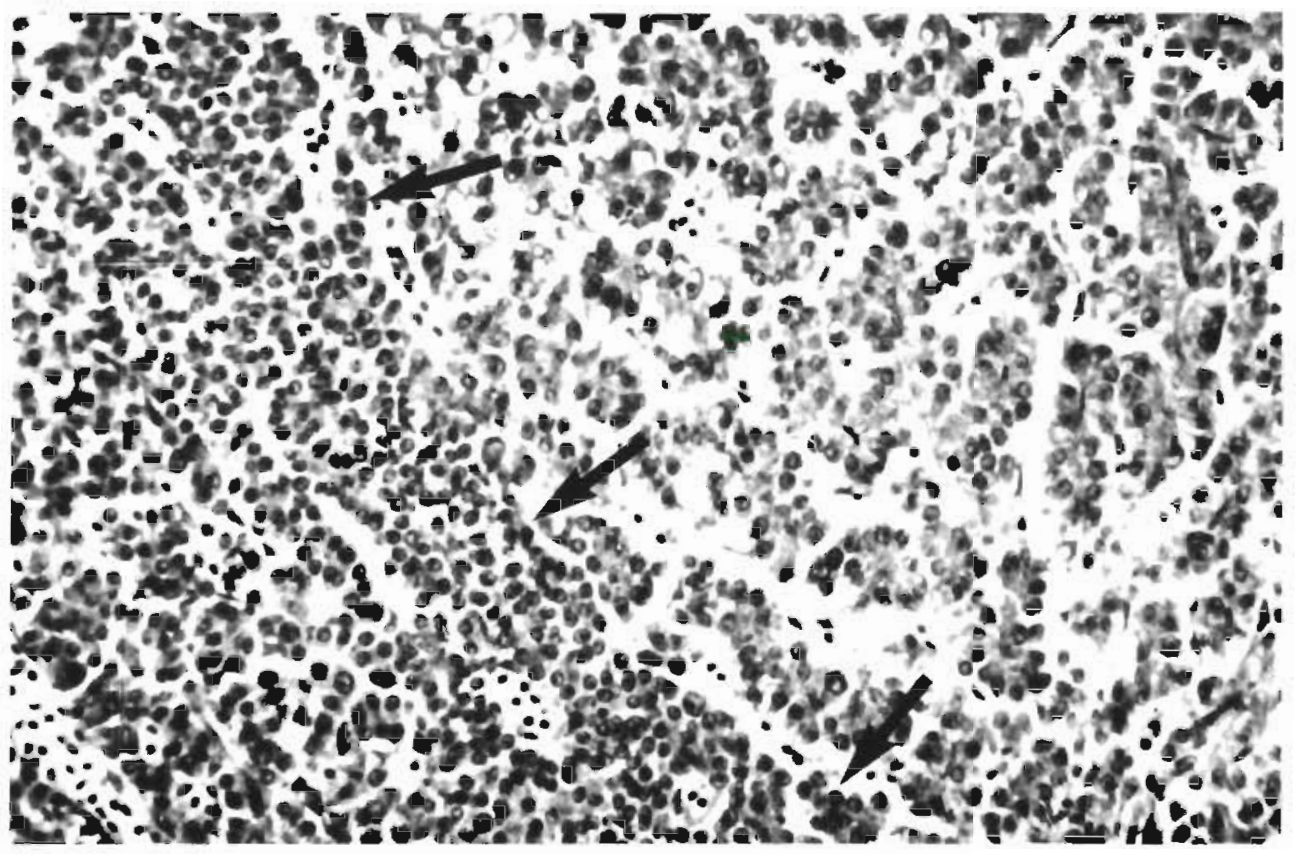

Fig. 7. Gymnocephalus cernua. Neoplastic nodule (in part) in liver section of ruffe from the Lower Elbe; arrows mark the border against surrounding liver tissue which appears slightly compressed. LM; paraffin $5 \mu \mathrm{m} ; \mathrm{H} / \mathrm{E}_{;} \times 400$

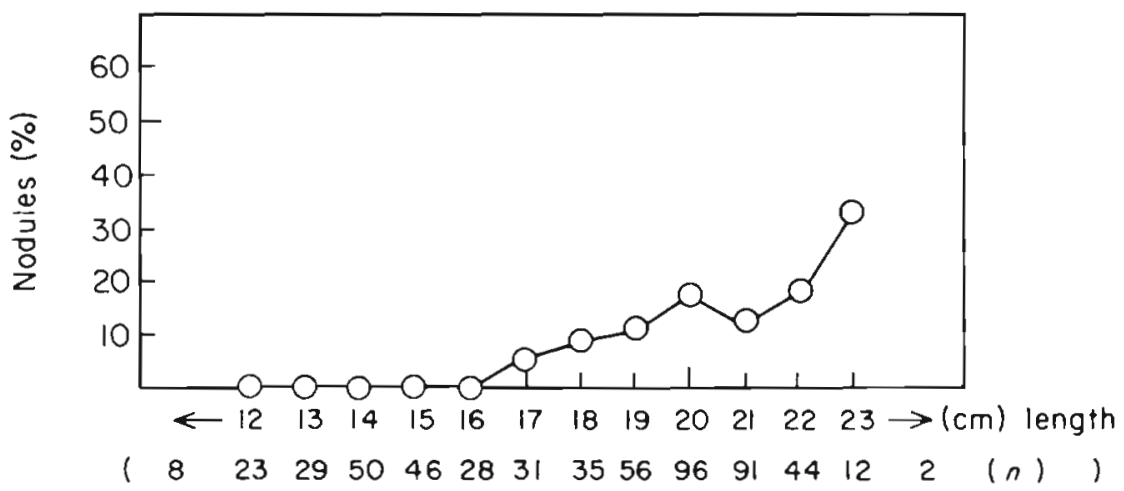

Fig. 8. Gymnocephalus cernua. Incidence of liver nodules in ruffe from the Lower Elbe in relation to body length

have revealed that neoplastic liver nodules are also present in sexually mature flounders greater than $30 \mathrm{~cm}$ in total length off the Dutch Coast. Local rates of occurrence reach $10 \%$ (Veethak pers. comm.). In light of the fact that the main spawning grounds of Elbe flounders are located off the Dutch Coast, it seems likely that the neoplastic changes in the flounder liver pass through a longer latent period than those of the ruffe. Possibly, this has to do with the longer time required to reach sexual maturity*

Another question is whether the liver nodules described are actually regenerative centers, which

\footnotetext{
- Because of their short life span, the smelt were not examined for neoplastic liver conditions
}

sooner or later cease their development, or whether, in fact, they are actual tumors, or hepatomas, with unlimited growth potential. Evidence for the first alternative is provided by the great potential for liver regeneration and by the fact that no malignant tumors, that is, liver carcinomas, have been observed. The second alternative is suggested by the very large diameters sometimes attained by the growths. Furthermore, in the largest of these tumors, exceeding $5 \mathrm{~mm}$ in diameter, central necrotic regions begin to form, similar to those characteristic of liver carcinomas. Naturally, there is also the possibility that some of the nodular formations observed in the liver are actually centers of regeneration and only some of them are tumorous growths. In either case, the liver nodules must be considered signs of progressive degeneration. 


\section{Melanomacrophage centers in the liver}

As already briefly mentioned, in the immediate vicinity of blood vessels in fish livers, groups of cells can be observed, which are prominent because of their more or less darkly pigmented inclusions. These apparently fulfill the function of ingesting and decomposing foreign material and the remains of broken-down tissues. If the complete breakdown of these substances is not possible, they must be stored in the cells (Ellis et al. 1976, Agius 1980, Wolke et al. 1985). Especially large accumulations of such stored material - massive deposits of very dense substance - are also designated residual bodies.

There is considerable variation in the size and abundance of the melanomacrophage centers. As a fish increases in age, an increase in the number of these cells or of their inclusions is generally observed. In spite of this variability, and although no exact quantitative evaluations are reported, histological examinations of a large number of individuals has shown very clearly that flounders and ruffe from the Lower Elbe possess more and larger melanomacrophage centers than fishes from the Eider. Such centers are especially numerous in livers showing significant degrees of degeneration *. The liver nodules are free or nearly free of melanomacrophage centers, but in adjacent tissues, which are often compressed from the rapid growth of the nodules, they occur in greater than normal abundance. Apparently, there is an increased dumping of tissue remains or foreign substances in the livers of fishes from the Lower Elbe.

\section{DISCUSSION}

Pathological changes in organs and tissues are generally characterized by an obvious increase in morphological and physiological, or functional, variability, both within a single organism and from one individual to another. This increased variability results from the more frequent occurrence of individual symptoms in a variety of combinations. According to our present understanding of the biological structure and function of an organism, this reduces the degree of organization and the regularity of functioning. Under these circumstances, the diverse changes in the fish liver described above must be considered pathological, at least when they appear in combination.

The phenomenon of fatty liver, or better defined, the storage of large quantities of fats in the fish liver, is

\footnotetext{
- It is noteworthy that especially serious degenerative changes in livers eventually include disintegration of the melanomacrophage centers. After the dissolution of tissue integrity, these centers are less frequently observed
}

quite normal at certain times, including periods of sexual maturation, when both flounder and ruffe store considerable amounts of fat in the hepatocytes (Kranz $\&$ Peters 1985). A dietary imbalance is another especially common cause of fatty livers in cultured fishes (Hille et al. 1980). However, when the diet is normal, when the fishes are beyound the spawning season, and when a concurrent combination with other degeneration phenomena is observed, fatty livers must undoubtedly be considered pathological (Roberts 1978).

Storch \& Juario (1983) were able to induce shrinkage of the liver cells in postlarval, juvenile milk fish Chanos chanos by complete starvation for $9 \mathrm{~d}$, but this could not be repeated in fingerlings. Among larger fishes, which possess considerable energy reserves, this seems to be hardly possible. Segner \& Möller (1984) exposed 10 to $12 \mathrm{~cm}$ flounders to complete starvation for $60 \mathrm{~d}$, whereupon they determined, in addition to a certain parenchymal disarray and a proliferation of macrophages, that the hepatocytes had been reduced in size chiefly due to the loss of stored glycogen and fat. This decrease in size was not the same as the shrinkage of the hepatocytes that we described. In fact, Segner \& Möller observed that the hepatocytes had only been reduced in size and had scarcely changed their form. Furthermore, their nuclei and mitochondria were hardly ever distorted. Necroses seldom occurred. After a $5 \mathrm{~d}$ period of feeding, the hepatocytes had again become similar to those of the unstarved controls, even before histological integrity had been completely restored.

As a central metabolic organ, it should be expected that the liver would show reactions in its microstructure to dietary conditions. Although at first surprising, it is in any case understandable that the liver would clearly react and even show degenerative changes when the fish is exposed to such extreme nutritional conditions as complete starvation or very one-sided diets consisting of enormously disproportionate amounts of fats, carbohydrates, or protein (Storch \& Juario 1983, Storch et al. 1983a, 1984, Segner \& Moller 1984). The combination of such dietary stress with extreme temperatures enhances such reactions in the liver (Storch et al. 1983b). The fishes from the Elbe that we examined are certainly not exposed to these kinds of extreme environmental conditions. Möller (1984) rather confirmed that the nutritional conditions for flounders in the region we investigated are relatively good.

The degeneration processes that we observed in the livers of flounders and ruffe, as well as smelts, from the Lower Elbe exceed in many of their individual symptoms the intensity that Storch and his colleagues were able to induce experimentally by varying nutritional conditions, especially with regard to their prominence 
and simultaneous occurrence. Causes for the poor condition of the livers found in a large number of fish from the Elbe should not be sought in any unfavorable combination of natural environmental factors, but rather, in our opinion, in the high degree of pollution. The following reasons for this can be given:

(1) The livers of the control fishes captured in the Eider River are mostly free from symptoms. In comparison to the Elbe, the Eider can be considered only slightly polluted (Wassergüteuntersuchungen Eider $1979)$.

(2) The content of polychlorinated biphenyl (PCB) in the open water of the Lower Elbe was measured in the $\mu \mathrm{g}$ range, up to a maximum of $12 \mu \mathrm{gl}^{-1}$ in February 1978, taking deca-PCB as the standard (ARGE Elbe $1978,1982)^{\circ}$. After Couch (1975) exposure to concentrations of 1 to $12 \mu \mathrm{g} \mathrm{l}^{-1}$ of the PCB Aroclor 1248 for a year brought about progressive degeneration of lake trout livers. An Aroclor 1254 concentration of $5 \mu \mathrm{gl}^{-1}$ caused severe liver damage to spot Leiostomus xanthurus in only $3 \mathrm{wk}$. It resulted in the death of over $50 \%$ of these fishes. The PCB was actively deposited in the liver. Degenerative changes in the liver and increased mortality from the experimental effects of 1 to $10 \mu \mathrm{g} \mathrm{]^{-1 }}$ of PCB were also reported for various fish species by Roberts et al. (1978).

(3) Köhler \& Harms (unpubl.; see Köhler 1986) kept 1 yr old Elbe flounders in uncontaminated freshwater with an unlimited supply of uncontaminated food for $40 \mathrm{~d}$. After $20 \mathrm{~d}$, incipient liver regeneration was noted in 3 of 10 flounders. After $40 \mathrm{~d}, 4$ of the 10 livers were, in effect, fully regenerated, and shrinkage of the liver cells could no longer be detected. Incipient regeneration was observed in 3 of the others, but the final 3 still showed the degree of degeneration that they had at the start of the experiment. While a significant decrease in the chlorinated hydrocarbon, including $\mathrm{PCB}$, content of the regenerated and the regenerating livers was detected, the original level of contamination was maintained by those livers that did not regenerate. Significantly faster growth was displayed by those flounders with regenerated livers.

(4) Several fish populations inhabiting heavily polluted coastal water bodies were observed to have advanced liver degeneration and a high rate of affliction with liver tumors (Falkmer et al. 1976, 1977, Pierce et al. 1978, Smith et al. 1979, Malins et al. 1984, Murchelano \& Wolke 1985). During these investigations, also a concurrent, high PCB contamination of the fishes was noted. Within 5 yr after the prohibition of all

- If Clophen $A 60$ had been used as the standard, the values would have been about one order of magnitude lower (ARGE Elbe 1982). Since the second half of the year 1981, the PCB content of Elbe water seems to have decreased significantly
PCB use in Sweden, Falkmer et al. (1977) discovered that there had been a decline in the liver tumor occurrence in hagfish Myxine glutinosa from the Gullmar Fjord to about $1 / 10$ of its former rate.

From the 6 fundamental criteria mentioned at the beginning of this paper, which are required to designate a general or a specific kind of pollution as a primary or contributory cause of an observed fish disease, 4 (Nos. 3, 4, 5, and 6) have been at least partially met. We do not believe that there can be any further doubt that the pathologic liver symptoms described for flounder, ruffe, and smelt from the Lower Elbe are due essentially to the high level of water pollution, in which chlorinated hydrocarbons seem to play an important role.

\section{LITERATURE CITED}

Agius, C. (1980). Phylogenetic development of melano-macrophage centres in fish. J. Zool., Lond. 191: 11-31

ARGE Elbe (Arbeitsgemeinschaft für die Reinhaltung der Elbe) (1978). Wassergütedaten der Elbe von Schnackenburg bis zur See. Wassergutestelle Elbe, Hamburg

ARGE Elbe (Arbeitsgemeinschaft für die Reinhaltung der Elbe (1982). Chlorierte Kohlenwasserstoffe - Daten der Elbe von Schnackenburg bis zur See 1980-1982. Wassergütestelle Elbe, Hamburg

Couch, J. A. (1975). Histopathological effects of pesticides and related chemicals on the livers. In: Ribelin, $W$ E., Migaki, G. (ed.) The pathology of fishes. Univ. of Wisconsin Press, Madison, p. 559-584

Dethlefsen, V (1985). Krankheiten von Nordseefischen als Ausdruck der Gewässerbelastung. Abh. Naturw. Verein Bremen 40/3: 233-252

Dethlefsen, V., Tiews, K. (1985). Review on the effects of pollution on marine fish life and fisheries in the North Sea. Z. angew. Ichthyol. 1 (3): 97-118

Ellis, A. E., Munro, A. L. S., Roberts, R. J. (1976). Defense mechanisms in fish. I. A study of the phagocytic system and the fate of intraperitoneally injected particulate material in plaice (Pleuronectes platessa). J. Fish Biol. 8: $67-78$

Falkmer, S., Emdin, S. O., Ostberg, Y., Mattisson, A., Johansson-Sjöbeck, M.-L., Fänge, R. (1976). Tumor pathology of the hagfish, Myxine glutinosa, and the river lamprey, Lampetra fluviatilis. Prog. exp. Tumor Res. 20: 217-250

Falkmer, S., Marklund, S., Mattisson, P. E., Rappe, C. (1977). Hepatomas and other neoplasms in the Atlantic hagfish (Myxine glutinosa): a histopathologic and chemical study. Ann. N. Y. Acad. Sci. 298: 342-355

Hille, S., Deufel, J., Kausch, H., Platz, F. (1980). Entstehung eines Fettlebersyndroms bei Regenbogenforellen (Salmo gairdneri) in Abhängigkeit von Kohlenhydrat- und Proteingehalt des Futters sowie bei Überfütterung. Arch. Hydrobiol. Suppl. 59: 1-16

Knowles, C. M. (1974). Vorkommen, Verbreitung und Biologie der häufigsten Fischarten der Unterelbe unter besonderer Berücksichtigung der Plötze (Rutilus rutilus L.) und des Kaulbarsches (Acerina cernua L.). Diplomarbeit, Universität Hamburg

Köhler, A. (1980). Vorkommen und Gesundheitszustand von Flunder (Platichthys flesus) und Stint (Osmerus eperlanus) in der Unterelbe im Jahre 1978. Diplomarbeit, Universität Hamburg 
Köhler, A., Hölzel, F. (1980). Investigation on health conditions of flounder and smelt in the Elbe estuary. Helgoländer Meeresunters. 33: 401-414

Köhler, A. (1986). Mikroskopisch anatomische und ultrastrukturelle Untersuchungen an der Flunderleber (Platichthys flesus L.) aus unterschiedlich belasteten Astuaren. Dissertation, Universität Hamburg

Kranz, H., Peters, N. (1984). Melano-macrophage centres in Liver and spleen of ruffe (Gymnocephalus cernua) from the Elbe estuary. Helgoländer Meeresunters. 37: 415-424

Kranz, H., Peters, N. (1985). Pathological conditions in the liver of ruffe, Gymnocephalus cernua (L.), from the Elbe estuary. J. Fish Dis. 8: 13-24

Malins, D. C., McCain, B. B., Brown, D. W., Chan, S.-L. Myers, M. S., Landahl, J. T., Prohaska, P. G., Friedman, A. J., Rhodes, L. D., Burrows, D. G., Gronlund, W. D. Hodgins, H. O. (1984). Chemical pollutants in sediments and diseases of bottom-dwelling fish in Puget Sound, Washington. Environ. Sci. Technol. 18: 705-713

Möller, H. (1984). Daten zur Biologie der Elbfische. Verlag H. Möller, Kiel

Müller, G. (1985). Unseren Flüssen geht's wieder besser. Bild der Wissenschaft 10: 74-97

Murchelano, R. A., Wolke, R. E. (1985). Epizootic carcinoma in the winter flounder, Pseudopleuronectes americanus. Science 228: 587-589

Peters, N. (1981). Fischkrankheiten und Gewässerbelastung im Küstenbereich. Verh. dt. zool. Ges. 74: 16-30

Peters, N. (1984). Diseases caused by Neoplasia. In: O. Kinne (ed.) Diseases of marine animals, Vol. IV, Part 1 Biologische Anstalt Helgoland, Hamburg, p. 400-423

Pierce, K. V., McCain, B. B., Wellings, S. R. (1978). The pathology of hepatomas and other liver abnormalities in English sole (Parophrys vetulus) from the Duwamish river estuary, Seattle, Washington. J. natn. Cancer Inst. 60: 1445

Roberts, R. J. (1978). Fish pathology. Baillière Tindall, London

Roberts, J. R., Rodgers, D. W., Baily, J. R., Rorke, M. A. (1978). Polychlorinated biphenyls: biological criteria for an assessment of their effects on environmental quality. Nat. Res. Council of Canada, Publ. No. NRCC 16077. Ottawa
Segner, H., Möller, H. (1984). Electron microscopical investigations on starvation-induced liver pathology in flounders Platichthys flesus. Mar Ecol. Prog. Ser. 19: 193-196

Sindermann, C. J. (1979). Pollution-associated diseases and abnormalities of fish and shellfish: a reviw. Fish. Bull. U.S. 76: 717-749

Sindermann, C. J. (1983). An examination of some relationships between pollution and disease. Rapp. P.-v. Réun. Cons. int. Explor Mer 182: 37-43

Smith, C. E., Peck, T H., Klauda, R. J., McLaren, J. B. (1979). Hepatomas in Atlantic tomcod Microgadus tomcod (Walbaum) collected in the Hudson River estuary in New York. J. Fish Dis. 2: 313-319

Sondergutachten des Rates von Sachverständigen für Umweltfragen (1980). Umweltprobleme der Nordsee. W Kohihammer, Stuttgart und Mainz

Storch, V., Juario, J. V. (1983). The effect of starvation and subsequent feeding on the hepatocytes of Chanos chanos (Forsskal) fingerlings and fry. J. Fish Biol. 23: 95-103

Storch, V., Stählin, W., Juario, J. V. (1983a). Effect of different diets on the ultrastructure of hepatocytes of Chanos chanos fry (Chanidae: Teleostei): an electron microscopic and morphometric analysis. Mar. Biol. 74: 101-104

Storch, V., Welsch, U., Schunke, M., Wodtke, E. (1983b). Einfluß von Temperatur und Nahrungsentzug auf die Hepatocytgen von Cyprinus carpio (Cyprinidae, Teleostei). Zool Beitr. N. F. 28: 253-269

Storch, V., Juario, J. V., Pascual, F. P. (1984). Early effects of nutritional stress on the liver of milkfish, Chanos chanos (Forsskal), and on the hepatopancreas of the tiger prawn, Penaeus monodon (Fabricius). Aquaculture 36: 229-236

Wassergüteuntersuchungen Eider (1979). Untersuchung des Zustandes und der Benutzung der Eider von Rendsburg bis zur Mündung. Landesamt für Wasserhaushalt und Küsten Schleswig-Holstein, Kiel

Wolke, R. E., Murchelano, R. A., Dickstein, C. D., George, C. J. (1985). Preliminary evaluation of the use of macrophage aggregates (MA) as fish health monitors. Bull. Environ. Contam. Toxicol. 35: 222-227 